\title{
1. Introduction to the Handbook on Theories of Governance
}

\author{
Christopher Ansell and Jacob Torfing
}

Concepts and approaches come and go in the social sciences. Some of them are more than passing moments and become steadily growing research areas that attract increasing scholarly attention. Some of the new research areas are stabilized and consolidated and gradually take the form of new paradigms that signal a scientific turn and give rise to a significant reorientation of the scholarly activities of researchers and the ideas and actions of practitioners. The research on governance has recently evolved into such a paradigm. Although the notion of governance can be traced far back into history, the interest in governance surged in the 1990s and has grown ever since. Today, governance is one of the most frequently used social science concepts in the world, as any internet search will readily confirm. A vast array of researchers, research centers, journals and conferences are devoted to the study of governance, and many new theories of governance have been promulgated over the last two decades.

Theories of governance are analytical lenses that help us understand our contemporary world. These theories have different purposes. Some of them bring into focus how different actors, jurisdictions, levels and institutional arenas interact to exchange knowledge and ideas, coordinate action and collaborate in making authoritative decisions that produce collective outcomes. Others help us understand the role played by different public, private and civil society actors in governing processes at different levels and in different countries or parts of the world. Some theories help us analyze how governance is designed, organized and orchestrated, or how it evolves over time and across sectors and domains. Others measure governance, study its impact and effects or help us to understand how different kinds of governance contribute to more effective, democratic or innovative ways of solving societal problems, delivering public services or regulating social and economic life. Still others analyze governance failure or how to improve governance to secure desirable outcomes. Collected together, these theories of governance provide an analytical tool kit for reflecting on and participating in the production of ordered rule in our increasingly complex, fragmented and dynamic society.

This Handbook provides an overview of theories of governance. As the individual chapters in this volume suggest, the reach of governance theory is broad and its empirical terms of reference are highly varied - from managing local mental health services to addressing global environmental problems. Governance theory is also a particularly interdisciplinary endeavor - with roots in political science, public administration, sociology, economics and law and with branches that extend into many applied fields. What we hope to make clear with this volume is that governance researchers share — or at least have at their disposal — a rich and powerful set of theories that enable us to address a wide range of issues. By focusing on "theories" of governance, this Handbook celebrates the diversity of ideas that have grown up in this relatively young field of research. There is no single "theory" of governance, but rather many overlapping theoretical discussions and debates. By collecting these discussions and debates together in a single volume, we hope to demonstrate the formidable strength of our shared 
conceptual tool kit. By assembling these theories in a single place, we also hope to clarify the baseline for subsequent theoretical development and refinement.

To establish a common framework for the chapters that follow, we first define the concept of governance and specify the basic understanding of governance that informs the contributions to this Handbook. We then explore the rise and development of the governance debate in Western liberal democracies and other parts of the world. Having defined the concept of governance and explored its origins, we reflect on the content and purpose of theories of governance and the need for a Handbook dedicated to the exposition of these theories. This need arises from the rapid expansion of empirical studies of governance that prompts us to consolidate, assess and further develop the theoretical foundations of this field. At the end of the Introduction, we briefly explain the purpose and content of the four main parts of the Handbook and outline the different ways that it can be used.

\section{DEFINING GOVERNANCE}

Today, "governance" is one of the most fashionable and frequently used social science terms in the world. Part of the attraction is that the notion of governance signals a weakening of the state-centric view of power and societal steering that has been problematized by recent empirical and ideological developments. Another and related part of the attraction is that "governance" perceives private and civil society actors as resources and instruments for co-produced public policy making, instead of reducing them to passive targets and subjects of public regulation. This view chimes well with the post-liberal call for the development of an active citizenship and the post-modern decentering of power. Both tend to draw attention to the idea of "regulated self-regulation," which encourages individual and collective actors to interact in relatively autonomous arenas facilitated and regulated by public authorities aiming to govern at a distance (Sørensen and Triantafillou 2009).

Governance is a popular but notoriously slippery term. This is evidenced by the fact that governance is often used in conjunction with a particular qualifying prefix. Hence, "good governance" tends to refer to the endeavor of international organizations such as the United Nations and the World Bank to assess and measure the quality of governing institutions in developing countries in terms of their stability, interaction, transparency, responsiveness, procedural fairness, effectiveness and adherence to the rule of law. "Global governance" refers to attempts to devise regulatory policies in response to global problems such as AIDS, terrorism, poverty and global warming in the absence of an overarching political authority. "Corporate governance" refers to the institutionalized interaction among the many players-including shareholders, management, boards of directors, employees, customers, financial institutions, regulators and the community at large - involved in the process of directing and controlling private firms. "Multi-level governance" refers to a system of continuous negotiation among nested governments at the local, regional, national and supranational levels. Last but not least, it should be mentioned that "new governance" has been a buzzword in public sector reforms inspired by New Public Management (NPM). The governance literature contains many other conceptual constellations that further expand the application of the notion of governance. However, adding a particular prefix to the notion of governance does not help us in defining what governance per se means. Thus we need a generic definition of governance that can 
subsequently be used in radial categorizations of different kinds of governance (Torfing et al. 2012).

Some contemporary commentators have defined governance in terms of: the formation of a collective will out of a diversity of interests (politics); a system of rules shaping and regulating the actions of social and political actors (polity); or the political steering of social and economic relations based on soft, cooperative policy instruments, such as persuasion, voluntary coordination and procedures for benchmarking public performance (policy) (for an overview see Treib et al. 2005). However, these different definitions do not really capture the distinctiveness of governance, because they fail to show what governance adds to the more familiar political science notions of politics, polity or policy.

Let us, therefore, briefly consider some of the alternative definitional strategies that have been advocated by leading scholars in the field of governance studies. First, the World Bank (2007) defines governance in terms of: the process of selecting those capable of making authoritative political decisions; the capacity of the government to effectively manage its resources and implement sound policies; and the respect that citizens and governments have for the institutions governing their interactions. The problem with this definitional strategy is not only its prescriptive character but also that it betrays the fundamental idea that governance implies a problematization of the role and nature of unicentric forms of government. Although it does make a reference to institutionalized forms of interaction, the World Bank definition of governance is primarily focused on the institutions and procedures of traditional forms of government.

Second, Jessop $(1998,2002)$ defines governance as "the heterarchy of reflexive self-organisation." This definition tends to associate governance with self-organized processes in civil society. The problem with this definitional strategy is that it gives rise to an unwarranted normativism, as it implicitly assumes that governance is more consensual, egalitarian, trust-based and deliberative than governing produced by State and markets because it reproduces the intrinsic values of civil society.

Third, Kooiman (1993), Mayntz (1993a, 1993b), Scharpf (1994) and Klijn (2008) tend to equate governance with network forms of governance that are defined either as a hybrid of hierarchy and market or as a distinctive mode of governing that supplements hierarchies and markets. Although networks are clearly an integral part of governance, the conflation of governance and networks creates an overly narrow definition of governance that excludes those forms of steering, control and coordination that are not provided by stable, horizontal networks.

Finally, Bevir and Rhodes (2003) tend to see governance as a neoliberal language game that leads to different interpretations and institutionalizations in different political and cultural contexts. The problem with this post-foundationalist view is that it becomes difficult to put bounds on governance. It does not refer to specific institutions, processes or modes of governing, so governance is reduced to a narrative advanced by situated actors addressing particular dilemmas in ways that are contingent upon specific traditions.

The problem with the available definitional strategies is that they either define governance too narrowly or leave the definition open for an endless number of contextual interpretations. To avoid these pitfalls, we shall here define governance generically as the process of steering society and the economy through collective action and in accordance with common goals (Torfing et al. 2012). This definition resonates with Meuleman's definition of governance as 
any pattern of ordered rule (Meuleman 2008) but is more precise, as it tells us what is governed and how it is governed.

Building on this broad definition, this Handbook will emphasize the interactive dimensions of public governance and thus more narrowly define governance as the interactive processes through which society and the economy are steered towards collectively negotiated objectives. The crucial insight is that no single actor has the knowledge, resources and capacities to govern alone in our complex and fragmented societies (Kooiman 1993). Interaction is needed in order to exchange or pool the ideas, resources and competences that are required for the production of desirable outcomes.

\section{THE RISE AND DEVELOPMENT OF THE GOVERNANCE DEBATE}

The new focus on "governance" - a term difficult to translate across different languages - was triggered by the problematization of traditional forms of government. The idea pervading liberal democracies that social and economic relations are - and indeed should be - governed solely through a "chain of government" connecting voters, parliamentary assemblies, executive political leaders, public bureaucracy and citizens through a series of delegation and control relations was criticized for being too formalistic, narrow-minded, exclusive, inflexible, uncoordinated, "undemocratic" and, most importantly, out of step with reality. The contemporary focus on governance arose through an inversion of this reigning conception of governing - the critical acts of governing often occurred outside the formal chain of government in the interaction of a plethora of public and private actors. The normative logic was inverted as well. Only by acknowledging the centrality of these extra-governmental interactions could we expect to achieve competent and knowledge-based decision making, creative problem solving, and flexible and well-coordinated policy implementation. Moreover, it was assumed that governance would help to realize democratic ideals about inclusion, empowerment and ownership and provide opportunities for societal actors to influence and perhaps even co-create policy, regulation and public services at the output side of the political system. Last but not least, governance would provide a more realistic account of the actual forms of governing society and the economy by taking into account the complex patterns of networked interaction that break with the linearity of the chain of government.

Theoretical inversion is a well-trod path to criticism. Arguably, many of the most important developments in the history of the social sciences have emerged in this way. In political science, pluralist theories inverted the narrow association of politics with formal constitutional and legal processes, focusing it instead on the political demands of interest groups. Behavioralism relocated the locus of attention from elites and placed it on the attitudes and behavior of ordinary citizens. Institutionalism then rebelled against behavioralism, arguing that institutions rather than individual attitudes and behaviors are the most important focus of politics. Theoretical inversions reveal unrecognized dynamics, raise new analytical questions and chart new directions for research. However, they also tend to invoke strong criticism. As path-breaking early statements give way to the work of theoretical elaboration and refinement, second generation theorists often wrestle with this legacy as they respond to critics. These elaborations and refinements are themselves often critical contributions to the emerging paradigm, sometimes breaking new theoretical ground and opening up further lines of research. 
The development of governance theory has definitely followed this path. Early statements invoking the idea of a shift from government to governance suggested that processes of governing were somehow self-organizing and did not require government. Critics pounced. As a result, governance scholars refined their bold claims, clarifying that governance did not replace government, but rather supplemented and transformed it. They noted how governance often operates in the "shadow" of government or that government participates in governance in distinct ways (as a "meta-governor"). The first generation of governance scholarship made a Faustian bargain by focusing on the positive aspects of governance and ignoring its darker and more problematic aspects, such as the precariousness of interactive forms of governance, the development of insurmountable conflicts and the lack of democratic accountability (Peters and Pierre 2004: 76). Subsequent scholarship responded by exploring this "dark side" (Raab and Milward 2003) and by elaborating new understandings of accountability (Considine 2002).

To say that the concept of governance emerged simply through a creative act of theoretical inversion would miss the wider political currents and theoretical concerns that contributed to its development. Different intellectual communities converged on the concept of governance because a common question arose from the early 1970s onwards across multiple domains: how can we govern effectively and democratically in a world in which political authority, capacity and power are fragmented, distributed or constrained? In the fields of public administration, public law and public policy, this question arose out of the attempt to address challenges posed by administrative complexity, poor policy implementation and fiscal austerity. In the field of development studies, it developed in response to the frustration of achieving development goals in partnership with weak or corrupt developing states. In the field of international relations, economics and environmental studies, the question grew out of the need to address collective action problems and the management of common pool resources. In EU studies, it arose from the emerging challenge of governing across levels of government. From the perspectives of empirical democratic theory or planning, it emerged from discussions about how to accommodate and enhance political input from citizens and private stakeholders. In organization theory, it arose from the need to understand how interorganizational relationships could be coordinated. Each domain produced specific theoretical responses, and terms like network governance, good governance, corporate governance, global governance, multi-level governance and democratic governance were born. Over time, however, there was increasingly cross-fertilization between these domains. Governance-and indeed interactive governance-was the common theme.

The concept of governance arose, in part, through a fundamental problematization of the role and function of the State. One source of this problematization can be traced back to the Trilateral Commission (Crozier et al. 1975), which initiated a world-wide discussion about the "overload of government" supposedly resulting from the mounting expectations of citizens, on the one hand, and the limited public resources and the low productivity growth in the public sector, on the other. The overburdening of public welfare systems allegedly coincided with an increasing "ungovernability of society" caused by the decline of public-spirited values and a growing individualism that undermined the social and political cohesion of modern societies. This bleak diagnosis was particularly troublesome for Western European governments that had strong faith in the ability of public welfare systems to meet the citizens' rising demands for more and better welfare and also had high ambitions with regard to the ability of the State 
to govern society and the economy in ways that ensured growth, prosperity and democratic legitimacy.

The economic crisis that began in the early 1970s and continued well into the 1980s further contributed to what was generally known as "the legitimacy crisis of the modern welfare state" (Habermas 1975; Offe 1984). It was increasingly difficult to finance public welfare systems and to govern the contradictions of capitalist societies, and the result was a gradual erosion of the legitimacy of government that revealed itself in and through a growing distrust in elected politicians, who were accused of being unable to govern to the satisfaction of the people.

The economic and political crisis in the 1970s paved the way for neoliberal governments and policies that aimed to solve the problem of "government overload" by means of privatizing public enterprises, contracting out public services and commercializing the remaining public sector (Jessop 2002). In line with neoliberal ideology, NPM reforms sought to limit the role of elected government to the formulation of overall policy objectives and to place the responsibility for the production and delivery of public services in the hands of private contractors and public special-purpose agencies that were operating on the basis of contracts and economic agreements with central government authorities. In response to the increasing "ungovernability of society," NPM reforms aimed to deregulate the public sector and society in order to enhance the reliance on the self-regulating capacity of private markets and public quasi-markets in which private firms compete for public contracts and citizens can choose freely between different public and private contractors. At the same time, NPM aimed to strengthen executive leadership and management in the public sector in order to make it more efficient. The new managerialism was predicated on a distinction between "steering" and "rowing." Politicians and executive managers should define the overall goals and budget frames, while the responsibility for service production should be devolved to special-purpose agencies. The new managerialism not only wanted to "let the managers manage" but also sought to "make the managers manage" by subjecting them to intensified performance measurement and high-powered incentives. With the Anglo-Saxon countries as the epicenter, NPM reforms spread throughout the Western world and beyond in consecutive waves of public management reforms (Pollitt and Bouckaert 2004).

In European public administration, the concept of governance arose in part in response to the managerial challenges produced by NPM. In the countries where it caught on, the emphasis on contracting out, agencification and devolution resulted in an increasingly fragmented public sector, which in turn stimulated the need for institutional mechanisms that could provide horizontal coordination in order to avoid duplication of efforts and create synergies (Rhodes 1997). At the same time, an increasing number of traditional policy problems such as physical planning, regional development and environmental protection were re-described as "wicked problems," and a series of new crosscutting policy challenges such as the expansion of preventive health care, the enhancement of public safety and the improvement of the employability of the unemployed came to the fore (Klijn and Koppenjan 2004). This development further strengthened the call for horizontal coordination through institutionalized interaction among relevant public and private actors. New forms of joined-up government, relational contracts between public purchasers and private providers, public-private partnerships and governance networks were typical responses to the call for crosscutting coordination and multilateral action (Rhodes 2000). "Governance" referred to governing in and through distributed networks of agencies and contractors. 
In the field of international development, the concept had a different trajectory. Reflecting the economic success of "development states" in Asia and new research stressing the importance of basic legal and political institutions for the development of Western economies, academics and practitioners in the late 1980s converged on a belief that a well-functioning state was a critical pre-condition for successful economic development. The challenge, however, was that many developing states suffered from either weak capacity or extensive corruption. By calling attention to the institutional prerequisites of economic development, the discourse of "good governance" gave international development institutions a neutral language in which to address the vexing problem of corruption (Grindle 2010). While the use of the term "governance" in the setting of European public administration was a response to the fragmenting effects of NPM, international development agencies like the World Bank and the International Monetary Fund were more inclined to adopt managerial techniques under the banner of "good governance."

In the European Union (EU), the concept of governance also arose in response to a distinct set of themes related to the challenges of governing and to debates about the fundamental nature of the EU itself. "Intergovernmentalists" debated with "supranationalists" about what the EU was and what it was becoming. While this debate was fruitful, some scholars argued that it missed the important patterns of "multi-level governance" that were appearing (Marks 1993, 1996). The term "governance" also came to be applied to relatively novel forms of political integration - like the Open Method of Coordination - that reflected the desire to advance integration without upsetting member-state sovereignty. These novel forms of governance did this by advancing voluntary goals and standards and enforcing them through the "naming and shaming" of governments that failed to meet the agreed goals and standards. With the rapid progression of European integration in the 1990s and early 2000s, a concern about a "democratic deficit" also prompted thinking about governance. In order to remedy this problem, the European Commission (2001) and influential academic commentators (Scharpf 1999) recommended the creation of governance networks, partnerships and other forms of participatory governance. The argument was that the involvement of private stakeholders would help to enhance input and output legitimacy (Skelcher and Torfing 2010).

Both the development of the EU and globalization led scholars to reflect on basic ideas about states and statehood. Scholars like Bob Jessop (2002) argued we were witnessing a three-fold development that involved "the denationalization of statehood," "the destatification of politics" and "the internationalization of policy making." Others explored the way de-territorialization and re-territorialization were changing the relationship between state and nation (Ansell and Di Palma 2004). Old and new state powers were being displaced upwards to international and transnational organizations, downwards to local governments, public service agencies, user boards and local communities, and outwards to emerging cross-border regions and global networks. Consequently, state power came to be seen as being exercised at a variety of different and tangled scales. At the same time, the State was seen as gradually losing its monopoly on public policy making as an increasing number of private stakeholders such as interest organizations, NGOs, citizen groups, consultancy firms and private enterprises became involved in the formulation, implementation and evaluation of public policy. Some of these trends were surely exaggerated, but they nevertheless encouraged new thinking about how governing processes operated between or beyond states.

With the accentuation of debates about globalization, international relations scholars began to call attention to the serious challenges of managing global problems. While this was an old 
issue, scholars began to point to the way that "global governance" might differ from traditional management via international agencies (Rosenau and Czempiel 1992). Notably, NGOs came to be seen as playing a much larger role, either independently of or in partnership with UN agencies. Optimistic scholars began to talk of the international community of NGOs as analogous to a global civil society.

A distinctive characteristic of governance in all these situations was that governing was a distributed process engaging many stakeholders from different sectors and governing levels. Public goods economics problematized this distributed process by pointing out the pervasiveness of collective action problems (Olson 1974). If some stakeholders preferred to free ride on others, governance solutions would be suboptimal. Ideas about collective action were applied both to the anarchy of international political order and to much more local situations of resource management. One of the most important applications of these ideas was to environmental governance. In a landmark book, Elinor Ostrom examined the way that collective action dilemmas in the management of common pool resources could be overcome (Ostrom 1990). In addition to emphasizing the structure of incentives faced in the management of commons, she stressed the importance of local community and its reliance on mutual trust and solidarity as an informal mechanism of overcoming collective action problems.

The discipline of economics contributed in other important ways to the emerging discourse of governance. Building on the tradition of institutional economics, Oliver Williamson opened up the black box of the firm and conceived of it as a bundle of contracts. His transaction cost analysis of the decision to produce in-house or to contract out led him to conceive of the administration of the firm in terms of governance (Williamson 1996). Related work on principal-agent theory also opened up the black box of the firm, offering an analysis of how the delegation of authority was governed in hierarchical situations characterized by information asymmetries. Principal-agent theory particularly influenced New Public Management, as discussed above. These theoretical ideas about the governance of the firm interacted with a movement of shareholders that sought to increase shareholders' influence on managerial decisions in firms. It was the confluence of theoretical work opening up the black box of the firm and these struggles for control over firms that led to the discourse of "corporate governance." These ideas quickly spread around the world and became an important topic of research.

The decentering of power and authority that occurred in many of the fields just mentioned raised the puzzle of how more or less decentralized stakeholders could co-produce public solutions. An important line of inquiry in the governance literature therefore focused on interactive forms of governing involving continuous negotiation among interdependent actors. Interest in various forms of interactive governance was strengthened and supported by new developments in political science (Kenis and Schneider 1991). For example, the research on public steering and control conducted at the Max Planck Institute in Cologne (Marin and Mayntz 1991; Mayntz 1993a, 1993b) and at the Centre for Interdisciplinary Research in Bielefeld (Héritier et al. 1996) emphasized the systemic limitations of both hierarchies and markets. These limitations necessitated the development of new modes of governance based on mutual exchange between public and private actors. Jan Kooiman (1993) summarized the new insights in his famous claim that no single actor, public or private, has the knowledge and capacity to solve complex, dynamic and diversified problems. Kooiman and many of his Dutch colleagues perceived the formation of complex networks as the solution to this challenge (Kickert et al. 1997), while other researchers saw the formation of contract-based partnerships between public and private actors as the way forward (Hodge and Greve 2005). 
The focus on networks and partnerships resonated well with the work of British scholars who had been criticizing the classical notions of corporatism and neo-corporatism for their narrow focus on the tight cooperation among public authorities, trade unions and business organizations. In response, they developed a more open and flexible notion of policy networks that both covered relatively tight and exclusive policy communities and relatively loose and inclusive issue networks (Marsh and Rhodes 1992; Rhodes 1997; Marsh 1998). The new focus on policy networks as mechanisms of governance also gained a foothold in France (Le Galès and Thatcher 1995) and in Scandinavia (March and Olsen 1995; Pierre 2000).

In North America, similar developments occurred. One source of theoretical innovation was work on policy implementation, which tried to understand how administrative and political complexity could lead to policy failures. Another source of inspiration was political science studies of subgovernments - relatively stable configurations of congressional committees, executive agencies and interest groups. Building on this literature, Hugh Heclo (1978) observed a surge of networked forms of governance. He argued that policy decisions frequently are moved from macro-level policy systems involving the presidency, congressional leaders, the Supreme Court, mass media and the general public to policy sub-systems where issue-specific actors from the public and private sectors interact on the basis of interdependency. Other literature focused on the role of networks in policy implementation and service delivery (Provan and Milward 1995, 2001) and paid considerable attention to the question of how to manage collaborative networks (Agranoff and McGuire 1998, 1999, 2001; Meier and O'Toole 2001; Milward and Provan 2006). The North American research on network governance developed in splendid isolation from the European debates. At least in the early years of network governance research, there were few cross-references between the two bodies of governance research, but a transatlantic dialogue on these issues has recently emerged. This dialogue has expanded to include important contributions from Australian scholars, who have focused on the role of networks in providing welfare services (Considine 2002; Considine and Lewis 2003; Keast et al. 2004).

The focus on interactive governance through networks and partnerships also developed in the field of planning and organization theory, where the focus was on how stakeholders with different perspectives or interests could successfully collaborate to find common ground (Gray 1989; Healey 1997; Innes and Booher 2003). This interest in "collaborative governance" also developed in the field of public law (Freeman 1997) and in fields like natural resource management, education and public health (Ansell and Gash 2008). The idea of the importance of collaboration was extended to public management, which focused on interagency coordination and the involvement of relevant and affected actors (Agranoff and McGuire 2004).

Today, it is commonly accepted that public governing is not congruent with the formal institutions of government. In some areas and at some levels there is still considerable room for unilateral action on the part of the State and particular government agencies, and most public services and transfer payments are still handled by large-scale public bureaucracies, although increasingly in partnership with private firms and associations. Nevertheless, $m u l$ tilateral interaction through which a plethora of public and/or private actors collaborate to solve wicked and unruly problems, regulate economic processes and provide public services is gaining ground and becoming the norm in some sectors. In particular, in critical areas where public innovation and flexible service provision are in high demand, governance strategies that exploit new opportunities for exchanging and pooling resources or building bridges across 
bureaucratic silos have become a more and more prominent response (Klijn and Koppenjan 2004; Sabel and Zeitlin 2008).

\section{THEORIES OF GOVERNANCE}

This Handbook focuses on theories of governance rather than on empirical studies of governance. As such, it takes one step back from the empirical world of governance in order to chart, analyze and assess the theoretical landscape of governance research and the different theoretical concepts, approaches and accounts that it represents. The study of governance has been approached from different theoretical angles and has led to the development of new theories. The expanding field of governance studies has invoked a large number of theoretical concepts and also produced many new ones. There is no comprehensive and all-encompassing theory of governance, and the future development of such a theory seems neither likely nor desirable. The competing theoretical approaches and conceptualizations offer different analytical perspectives and tools that permit students of governance to mix and match them in their search for an appropriate theoretical framework for addressing a particular research problem or research question. Hence, a problem-driven study of contemporary forms of governance is better off choosing between a large array of sharp and distinctive special-purpose theories than relying on a blunt, unified all-purpose theory.

Theories of governance are analytical constructs that are developed through empirical observations, deductive reasoning and a good deal of imagination and creativity. As such, governance theories are abstract, though context-dependent, ways of reasoning that aim to define, understand and explain how contemporary societies are governed. Theories of governance will often implicitly or explicitly contain the following set of components: theoretically justified assumptions about the nature of the world; empirically verifiable presuppositions that help to define the scope and validity of the theory; concepts and categories aiming to capture different aspects of the object of analysis; theoretical principles and arguments enabling us to understand and explain trends, events and joint occurrences; normative judgments based on particular standards; and empirical generalizations and predictions based on inductive and deductive methods.

While theories cannot themselves be falsified, they sometimes give rise to hypotheses and even predictions that can be tested, or at least critically evaluated, through empirical studies. Although theories are often developed through a dialectical interaction with empirical studies, theoretically derived hypotheses tend to be under-determined by empirical observation, since a marginal reformulation of the theoretical framework and the implicit hypotheses will often be enough to accommodate recalcitrant facts (Quine 1951).

Theories are essential for good empirical work on governance. There is no pure and unmediated access to the world. We always look at social and political phenomena through a particular lens of analytical pre-understandings that help us see, make sense of and interpret particular aspects, events and relations rather than others. Thus the different theories of governance will tend to define different kinds of governance, provide descriptive typologies and advance interpretative schemes and causal models that direct the gaze of the researcher and facilitate a systematic analysis of governance processes based on well-defined concepts and theoretical stipulations about the conditions and drivers of social and political action and the nature and 
qualities of political institutions and socioeconomic structures. Indeed, it is a truism that there is nothing as practical as good theory!

While theory helps the researcher to make sense of the world and structure the analysis of empirical conditions, processes and outcomes, there are two pitfalls that must be avoided. The first pitfall is theoretical reification, while the second pitfall is impressionistic descriptivism. Theoretical reification emerges when researchers perceive concepts and other analytical constructs as having a real life existence and thus forget that they are merely partial and contingent attempts to make sense of the world by naming and interpreting it in a certain way. Theoretical reification can be avoided by insisting on the gulf between social reality and the theoretical constructs that we use to make sense of it. However, some theoretical concepts and arguments tend to creep into the language of lay actors who talk about governance networks, multi-level governance and metagovernance and thus make use of particular theoretical constructs as part of the object of analysis. This reflects the fundamental condition of the social sciences: we are interpreting a social world that interprets itself. Nevertheless, whether it is researchers or lay actors who deploy a particular set of concepts and arguments, we must insist that these are contingent theoretical constructs that only capture particular aspects of the phenomena that we aim to grasp.

By contrast, impressionistic descriptivism emerges when researchers aim to describe and analyze the world as it appears to them through a more or less random collection of observations and impressions that are neither informed nor structured by a systematic and consistent set of theoretical concepts and arguments. Impressionistic descriptivism must be avoided by recognizing that our empirical observations are always based on particular presuppositions and by making sure that they are based on relevant and theoretically justified categories and assertions.

The rise of the governance debate and the development of competing theories of governance have already spurred the publication of several handbooks of governance. However, we believe that there is an urgent need for a handbook that explores the theoretical underpinnings of the new research on governance and provides a systematic and accessible overview of the different approaches, theories and concepts that are used in this new and important research.

The recent attempts to explore and assess the governing of society and the economy from a governance perspective are for the most part based on empirical case studies aiming to describe, analyze and explain different forms of governance at multiple levels and in varying policy areas. The proliferation of empirical case studies has been valuable for expanding the field of governance research, but tends to fragment our theoretical understanding of governance. By focusing on theories of governance, as opposed to actual governance practices, this Handbook aims to counter the field's fragmentation by highlighting the implicit and explicit theoretical assumptions that guide the study of public governance.

The Handbook aims to identify the theoretical foundations of governance research across different social science disciplines in order to demonstrate the broad and interdisciplinary relevance of governance studies. It will define and discuss the theoretical concepts that are relevant to and frequently used in the study of governance in order to show how governance studies draw on central insights from adjacent theoretical fields. It will also provide an overview of competing analytical lenses for studying public governance in order to reveal the theoretical pluralism of the field. Last but not least, it will present and discuss theories of different forms of governance. The theoretical focus of the Handbook will help us to gauge the breadth of governance theory. It will also draw attention to the similarities and differences 
between different disciplinary approaches and identify theoretical problems and lacunas that call for further theoretical development.

\section{THE STRENGTHS OF GOVERNANCE THEORY}

Pollitt and Hupe (2011) have recently describe "governance" as a magic concept that is characterized not only by its conceptual broadness and ambiguity but also by its normative attractiveness, global marketability and tendency to obscure or even deny conflicts between different logics. While we acknowledge that the term governance has multiple applications and that governance theories are not always razor sharp and tidy, we also see a particular strength in governance theory: It encourages us to find imperfect answers to big questions about the changing conditions for ordered rule rather than perfect answers to small questions about the precise impact of different policies, services and regulations.

Building on our account of the emergence and nature of the new theories of governance, we advance four propositions highlighting the strength of the vast field of governance theory.

First, it is interesting to see that ideas about governance arose at roughly the same time in multiple intellectual disciplines. Although drawing on different perspectives and addressing different problems, these disciplines gradually converged upon similar ideas about new modes of governing. The multi-perspectival nature of governance theory is a major strength, as it allows us to describe the more or less institutionalized processes of decentered governing through which public value is negotiated, defined and produced using different but overlapping theoretical languages that each capture important aspects of the current transformation of the provision of ordered rule.

Second, in constructing governance theory, these different disciplines have built upon classical concepts from the social sciences, such as power, legitimacy or accountability. However, in order to better understand new situations and problems encountered in the world of governance, these classical concepts have been adapted, expanded and refashioned. In this way, governance theory contributes to developing and enriching classical social science concepts. Many concepts need to be rethought in order to make sense of the world of today in which the formal institutions of government at the national level are revealed as one amongst many co-governing public and private actors. The conceptual rethinking of classical concepts in the light of new challenges is a major achievement of governance theory.

Third, the convergence of different disciplines and theoretical traditions on the use of the notion of "governance" provides us with a boundary object that facilitates a fruitful theoretical exchange between theoretical perspectives that hitherto have lived in splendid isolation from one another. Hence, the overlapping focus on "governance" encourages theoretical cross-fertilization, as different theoretical perspectives can now begin to communicate with and learn from each other. The crosscutting theoretical dialogue about issues pertaining to governance research may lead to a blurring of the boundaries separating the different sub-disciplines within the social sciences. Thus the enhancement of interdisciplinary research can be counted as one of the key strengths of governance research.

Fourth, governance theory has been elaborated through a process of radial development as researchers have begun to add different adjectives or prefixes to the notion of governance. This trend has enabled governance researchers to apply the notion of governance to a broad range of empirical domains, for example economic governance, regulatory governance, collabora- 
tive governance, network governance and so on. The extension of the empirical relevance of governance theory to ever more areas is facilitated by the conceptual flexibility of the notion of governance and constitutes a major strength of governance theory.

From these four propositions, we see that the diversity of governance theories is a strength rather than a weakness. However, praising the broad appeal and relevance of this "magic concept" does not mean that we should not strive for definitional precision, theoretical coherence and analytical rigor in the future development of the field. Clear definitions and categories, well-crafted argument and sharp analytical tools are the telos of all scientific endeavors, but in the new and emerging field of governance research the scientific goals will have to be achieved through ongoing debate between different theoretical perspectives and different empirical applications. Such an enterprise represents a formidable intellectual challenge, since the different theoretical perspectives and sub-disciplines have different concerns and ideas about conceptual, theoretical and analytical demands.

\section{HOW THE HANDBOOK IS ORGANIZED}

One of the central purposes of the Introduction has been to demonstrate that there is both a degree of convergence in the governance literature and also a healthy theoretical diversity. Our goal is to provide an accessible point of entry into this rich body of theory. As with all such endeavors, there is more than one way that the volume could have been organized. In charting our own course, we built on four distinct goals that we had for the volume. First, we wanted to provide the intellectual and empirical context for theoretical developments pertaining to governance. Second, we wanted to represent the diversity of theoretical ideas and debates in this field. Third, we wanted to make the volume a point of reference for critical analytical concepts. And finally, we wanted to establish a strong theoretical baseline that might inspire future theoretical and empirical work in governance.

In order to provide intellectual and empirical context for theoretical developments, it is important to delineate how theories about governance have emerged in different disciplines. This is accomplished in Part I of the Handbook. While it would have been impossible (within the scope of this volume) to cover all relevant disciplines, we identify ten disciplines that have made very significant contributions to governance theory: collective action theory, organization theory, public management, planning, policy process frameworks, state theory, empirical democratic theory, public law, development studies and international relations. To provide context for the key theoretical ideas in each of these disciplines, the authors provide some degree of historical overview that illustrates how and why this discipline began to think in terms of governance. By organizing Part I around the theoretical contribution of different disciplines, the volume captures the interdisciplinary breadth of the governance field.

Part II of the Handbook identifies 16 core concepts for governance studies. These are concepts that reappear over and over again in different theoretical discussions. Each chapter on a core concept provides readers with rapid access to the theoretical debates about the focal points of concern in the practice of governance. The authors explain why these concerns are salient and how different theories can be used to understand them. By devoting significant chapters to this series of core concepts, the Handbook highlights our shared theoretical inheritance. These core concepts are basic analytical tools in the tool kit of governance research. 
Part III of the Handbook takes a different approach to governance theory. While Part I focuses on disciplinary developments, Part III focuses on distinctive approaches to the study of governance. We have identified 11 different social science approaches or vantage points: information-based governance, discourse theory, institutionalism, public choice, advocacy coalition theory, economic theory, governmentality, system analysis and complexity theory, narrative and interpretive theory, pragmatism and normative theory. Each of these analytical approaches contributes something important to our understanding of governance, but does so by bringing different assumptions, perspectives and prescriptions to the analysis. The purpose of Part III is to identify these assumptions, perspectives and prescriptions. Each chapter will explain how a particular approach offers a distinctive theoretical lens into our understanding of governance.

The final part of the Handbook (Part IV) provides an analysis of distinctive forms of governance. As with Part II on core concepts, each of the 13 chapters in Part IV provides an overview of a key idea in the governance debate. The purpose of this part is to familiarize readers with theories of particular forms of governance. Each chapter describes key conceptual and definitional issues associated with the form of governance and also describes its key empirical variants. This part of the volume will add to the basic conceptual tool kit for analyzing governance. By addressing central research questions related to each form of governance, these chapters offer ideas for future research.

We hope the Handbook will find a broad readership and that it will prove helpful in providing a solid theoretical basis for studying the multiple forms of governance. In particular we hope that people with a professional interest in governance issues will be able to use the Handbook to develop a broader and more comprehensive understanding of the conceptual and theoretical approaches to governance. We also hope that the Handbook will be used by established researchers who want to assess the breadth and content of different theories of governance, or by those looking for relevant theories that can help to frame and guide empirical studies of actual governance processes. Finally, we hope that graduate and postgraduate students will find the Handbook helpful in providing quick and easy access to core themes in the theoretical debate on governance and use it as a source for clarifying key concepts and for understanding the subtle differences between different theoretical concepts and approaches.

\section{REFERENCES}

Agranoff, R. and M. McGuire (1998), 'Multi-network management: Collaboration and the hollow state in local economic policy', Journal of Public Administration Research and Theory, 8 (1), 67-91.

Agranoff, R. and M. McGuire (1999), 'Managing in network settings', Review of Policy Research, 16 (1), 18-41.

Agranoff, R. and M. McGuire (2001), 'Big questions in public network management research', Journal of Public Administration Research and Theory, 11 (3), 295-326.

Agranoff, R. and M. McGuire (2004), Collaborative Public Management: New Strategies for Local Governments, Washington, DC: Georgetown University Press.

Ansell, C.K. and G. Di Palma (eds) (2004), Restructuring Territoriality: Europe and the United States Compared, Cambridge: Cambridge University Press.

Ansell, C.K. and A. Gash (2008), 'Collaborative governance in theory and practice', Journal of Public Administration Research and Theory, 18 (4), 543-571.

Bevir, M. and R.A.W. Rhodes (2003), Interpreting British Governance, London: Routledge.

Considine, M. (2002), 'The end of the line? Accountable governance in the age of networks, partnerships and joined-up services', Governance, 15 (1), 21-40. 
Considine, M. and J.M. Lewis (2003), 'Bureaucracy, network, or enterprise? Comparing models of governance in Australia, Britain, the Netherlands, and New Zealand', Public Administration Review, 63 (2), 131-140.

Crozier, M., S.P. Huntington and J. Watanuki (1975), The Crisis of Democracy, New York: New York University Press.

European Commission (2001), European Governance, COM(2001) 428 final, Brussels.

Freeman, J. (1997), 'Collaborative governance in the administrative state', UCLA Law Review, 45, 1-98.

Gray, B. (1989), Collaborating: Finding Common Ground for Multiparty Problems, San Francisco, CA: Jossey-Bass.

Grindle, M. (2010), 'Good governance: The inflation of a concept', Faculty Working Paper Series no. RWP10-023, Harvard University, Kennedy School of Government.

Habermas, J. (1975), Legitimation Crisis, Boston, MA: Beacon Press.

Healey, P. (1997), Collaborative Planning: Shaping Places in Fragmented Societies, Vancouver: UBC Press.

Heclo, H. (1978), 'Issue networks and the executive establishment', in A. King (ed.), The Political System, Washington, DC: American Enterprise Institute for Public Policy Research, pp. 87-107.

Héritier, A., C. Knill and S. Mingers (1996), Ringing the Changes in Europe, Berlin: Walter de Gruyter.

Hodge, G. and C. Greve (2005), The Challenge of Public-Private Partnerships, Cheltenham, UK and Northampton, MA, USA: Edward Elgar.

Innes, J.E. and D.E. Booher (2003), 'Collaborative policymaking: Governance through dialogue', in M.A. Hajer and H. Wagenaar (eds), Deliberative Policy Analysis: Understanding Governance in the Network Society, Cambridge: Cambridge University Press, pp. 33-59.

Jessop, B. (1998), 'The rise of governance and the risks of failure: The case of economic development', International Social Science Journal, 50 (155), 29-45.

Jessop, B. (2002), The Future of the Capitalist State, Cambridge: Polity.

Keast, R., M.P. Mandell, K. Brown and G. Woolcock (2004), 'Network structures: Working differently and changing expectations', Public Administration Review, 64 (3), 363-371.

Kenis, P. and V. Schneider (1991), 'Policy networks and policy analysis: Scrutinizing a new analytical toolbox', in B. Marin and R. Mayntz (eds), Policy Networks, Frankfurt am Main: Campus, pp. 25-59.

Kickert, W.J.M., E.-H. Klijn and J.F.M. Koppenjan (eds) (1997), Managing Complex Networks, London: Sage.

Klijn, E.-H. (2008), 'Governance and governance networks in Europe', Public Management Review, 10 (4), 505-525.

Klijn, E.-H. and J.F.M. Koppenjan (2004), Managing Uncertainties in Networks, London: Routledge.

Kooiman, J. (ed.) (1993), Modern Governance, London: Sage.

Le Galès, P. and M. Thatcher (eds) (1995), Les Réseaux de Politique Publique: Débats autour des Policy Networks, Paris: L'Harmattan.

Marin, B. and R. Mayntz (eds) (1991), Policy Networks, Frankfurt am Main: Campus.

March, J.G. and J.P. Olsen (1995), Democratic Governance, New York: Free Press.

Marks, G. (1993), 'Structural policy and multi-level governance in the EC', in A. Cafruny and G. Rosenthal (eds), The State of the European Community: The Maastricht Debate and Beyond, Boulder, CO: Lynne Rienner, pp. 391-411.

Marks, G. (1996), 'An actor-centred approach to multi-level governance', Regional and Federal Studies, 6(2), 20-40.

Marsh, D. (ed.) (1998), Comparing Policy Networks, Buckingham: Open University Press.

Marsh, D. and R.A.W. Rhodes (eds) (1992), Policy Networks in British Government, Oxford: Oxford University Press.

Mayntz, R. (1993a), 'Modernization and the logic of interorganizational networks', in J. Child, M. Crozier and R. Mayntz (eds), Societal Change between Markets and Organization, Aldershot: Avebury, pp. 3-18.

Mayntz, R. (1993b), 'Governing failure and the problem of governability: Some comments on a theoretical paradigm', in J. Kooiman (ed.), Modern Governance, London: Sage, pp. 9-20.

Meier, K.J. and L.J. O'Toole (2001), 'Managerial strategies and behavior in networks: A model with evidence from US public education', Journal of Public Administration Research and Theory, 11 (3), 271-294. 
Meuleman, L. (2008), Public Management and the Metagovernance of Hierarchies, Networks and Markets, Heidelberg: Physica Verlag.

Milward, H.B. and K.G. Provan (2006), A Manager's Guide to Choosing and Using Collaborative Networks, Networks and Partnerships Series, Washington, DC: IBM Center for the Business of Government.

Offe, C. (1984), Contradictions of the Welfare State, Cambridge, MA: MIT Press.

Olson, M. (1974), The Logic of Collective Action: Public Goods and the Theory of Groups, Cambridge, MA: Harvard University Press.

Ostrom, E. (1990), Governing the Commons: The Evolution of Institutions for Collective Action, Cambridge: Cambridge University Press.

Peters, B.G. and J. Pierre (2004), 'Multi-level governance and democracy: A Faustian bargain?', in I. Bache and M. Flinders (eds), Multi-level Governance, Oxford: Oxford University Press, pp. 75-92.

Pierre, J. (2000), Debating Governance, Oxford: Oxford University Press.

Pollitt, C. and G. Bouckaert (2004), Public Management Reforms, Oxford: Oxford University Press.

Pollitt, C. and P. Hupe (2011), 'Talking about government: The role of magic concepts', Public Management Review, 13 (5), 641-658.

Provan, K.G. and H.B. Milward (1995), 'A preliminary theory of interorganizational network effectiveness: A comparative study of four community mental health systems', Administrative Science Quarterly, 40, 1-33.

Provan, K.G. and H.B. Milward (2001), 'Do networks really work? A framework for evaluating public sector organizational networks', Public Administration Review, 61 (4), 414-423.

Quine, W.V.O. (1951), 'Two dogmas of empiricism', Philosophical Review, 60 (1), 20-43.

Raab, J. and H.B. Milward (2003), 'Dark networks as problems', Journal of Public Administration Research and Theory, 13 (4), 413-439.

Rhodes, R.A.W. (1997), Understanding Governance, Buckingham: Open University Press.

Rhodes, R.A.W. (2000), 'The governance narrative: Key findings and lessons from the ESRC's Whitehall Programme', Public Administration, 78 (2), 345-364.

Rosenau, J.N. and E.O. Czempiel (eds) (1992), Governance without Government: Order and Change in World Politics, Cambridge: Cambridge University Press.

Sabel, C.F. and J. Zeitlin (2008), 'Learning from difference: The new architecture of experimentalist governance in the EU', European Law Journal, 14 (3), 271-327.

Scharpf, F.W. (1994), 'Games real actors could play: Positive and negative coordination in embedded negotiations', Journal of Theoretical Politics, 6 (1), 27-53.

Scharpf, F.W. (1999), Governing in Europe: Effective and Democratic?, Oxford: Oxford University Press.

Skelcher, C. and J. Torfing (2010), 'Improving democratic governance through institutional design: Civic participation and democratic ownership in Europe', Regulation and Governance, 4 (1), 71-91.

Sørensen, E. and P. Triantafillou (2009), The Politics of Self-governance, London: Ashgate.

Torfing, J., B.G. Peters, J. Pierre and E. Sørensen (2012), Interactive Governance: Advancing the Paradigm, Oxford: Oxford University Press.

Treib, O., H. Bähr and G. Falkner (2005), 'Modes of governance: A note towards conceptual clarification', European Governance Papers no. N-05-02.

Williamson, O.E. (1996), The Mechanisms of Governance, Oxford: Oxford University Press.

World Bank (2007), A Decade for Measuring the Quality of Governance, Washington, DC: World Bank. 